\title{
Thyroid Dysfunction in COVID-19
}

\author{
Nasser Mikhail* and Soma Wali \\ Endocrinology Division, David-Geffen-UCLA Medical School, USA
}

Submission: August 12, 2020; Published: September 04, 2020

*Corresponding author: Nasser Mikhail, Endocrinology Division, Department of Medicine, Olive-View UCLA Hospital, David-Geffen-UCLA Medical School, CA, USA

\section{Abstract}

Background: Preliminary data suggest that thyroid dysfunction may occur in association with coronavirus disease-2019 (COVID-19).

Objective: To clarify the link between COVID-19 and thyroid function.

Methods: PubMed search of English literature until August 11, 2020. Since there is lack of randomized trials, case reports retrospective studies, and National guidelines are reviewed.

Results: Retrospective studies suggest that 7-34\% of patients with COVID-19 admitted to the hospital display thyroid hormone alterations consistent with non-thyroidal illness. Severity of thyroid hormonal abnormalities correlate with severity of COVID-19. Only 4 well-documented cases of subacute thyroiditis were reported in association with infection with COVID-19. Less commonly, de novo autoimmune Hashimoto's hypothyroidism was reported in COVID-19.

Conclusion: Alterations of thyroid hormones due to non-thyroidal illness are common in COVID-19, whereas other thyroid diseases seem uncommon or underreported. Evaluation of thyroid function should be considered in patients with COVID-19 with symptoms or signs pertinent to thyroid function.

Keywords: Thyroid; COVID-19; Hyperthyroidism; Thyroiditis; Hypothyroidism; Autoimmune

\section{Introduction}

Although the lungs represent the primary target of COVID-19, accumulating studies suggest that it is a systemic disease. In the meantime, the virus causing COVID-19, the severe acute respiratory syndrome coronavirus-2 (SARS-Cov-2), uses angiotensin-converting enzyme 2 (ACE2) as receptor to enter host cells [1]. These receptors have widespread distribution in the human body [2]. In fact, Li et al [2] have demonstrated that ACE2 expression levels were highly present in the human thyroid tissue. Available data suggest that many hospitalized patients with COVID-19 exhibit non-thyroidal illness like patients admitted with other diseases. In addition, few case reports recorded patients with COVID-19 who developed subacute thyroiditis that may occur during or shortly after viral illnesses. The purpose of this article is to review the impact of COVID-19 on thyroid function based on limited available data.

\section{Non-Thyroidal Illness in Critically ill Patients in General}

In critically patients, irrespective of the underlying cause of illness, there are characteristics thyroid hormone changes that

generally correlate with the underlying disease severity [3-5]. The commonest and earliest thyroid hormone change is the drop of levels of triiodothyronine (T3), hence non-thyroidal illness is also named the low T3 syndrome $[3,4]$. The reason of low T3 is the inhibition of conversion of thyroxine (T4) to T3 by the enzyme type 1 deiodinase $[3,4]$. There is also mild suppression of thyrotropin or thyroid stimulating hormone (TSH) in the beginning of illness, and typically TSH rises and even becomes slightly elevated during recovery. In non-thyroidal illness, plasma levels of thyroxine (T4) are either low normal or frankly low [3,4]. It has been shown that reduction in circulating levels of $\mathrm{T} 3$ and $\mathrm{T} 4$ correlate inversely 
with mortality i.e, the lower the levels of thyroid hormones, the higher the mortality. Normalization of thyroid hormones occurs spontaneously after resolution of critical illness. The mechanisms of non-thyroidal illness are not fully understood. There is still debate whether non-thyroidal illness represents an adaptive or mal-adaptive response in the face of severe systemic illness $[3,4]$. Indeed, the few randomized trials of thyroid hormone treatment to patients with patients with non-thyroidal illness did not show any benefit and possible harm. Therefore, most experts do not recommend thyroid hormone therapy in non-thyroidal illness.

\section{Non-Thyroidal Illness in COVID-19}

Li et al [5] compared several laboratory results of 40 patients admitted to hospital with non-severe COVID-19 with age- and sexmatched 57 healthy control subjects. They found that (mean \pm SD) circulating levels of free T3 were significantly lower than control subjects, $4.57 \pm 0.8$ and $5.29 \pm 0.9 \mathrm{pmol} / \mathrm{L}$, respectively; $\mathrm{P}<0.0001$ [5]. Likewise, corresponding plasma levels of TSH were slightly but significantly lower in patients with COVID-19 than in control individuals, $2.13 \pm 0.9$ and $2.75 \pm 1.3 \mu \mathrm{IU} / \mathrm{ml}$, respectively; $\mathrm{P}<$ 0.017 [5]. In both groups, free T3 and TSH values remained within the normal range. These TSH and free T3 changes are suggestive of mild non-thyroidal illness that correspond to the "non-severe" COVID-19. Unfortunately, thyroxine levels were not measured in this study [5]. In a retrospective study from China of 336 patients with COVID-19 admitted to the hospital, Sun et al [6] reported that 26 patients (7.7\%) had severe/critical COVID-19 (definition was not provided).

These workers found that plasma levels of total T3, free T3 and free $\mathrm{T} 4$ were significantly lower in patients with severe/ critical disease compared with subjects with non-severe disease (actual levels of hormones were not provided) [6]. Again, the latter results are consistent with the fact that patients with severe/ critical COVID-19 had non-thyroidal illness. In a retrospective Chinese study, Chen et al [7] found that 34\% (28 of 50) of patients with COVID-19 admitted to the hospital had subnormal TSH levels. In addition, they found that levels of TSH and total T3 were significantly lower than a control group of healthy subjects and another control group of non-COVID-19 pneumonia [7]. Moreover, the degree of decreases of TSH and total T3 correlated positively with severity of COVID-19 [7].

However, levels of total T4 did not differ between the 3 groups. Importantly, as expected in non-thyroidal illness, after recovery from COVID-19, thyroid hormone values normalized without any thyroid-directed therapy [7]. In addition to its retrospective design, one limitation of the latter study was the fact that $62 \%$ (31 of 50) patients received methylprednisolone $57.3 \mathrm{mg} / \mathrm{d}$ (equivalent to approximately $60 \mathrm{mg}$ prednisone/d) [7]. This relatively high dose of glucocorticoids is known to suppress TSH secretion from the pituitary [8]. This may explain, at least in part, why Chen et al [7] observed that TSH levels in patients with
COVID-19 were significantly lower than in a group of patients with non-COVID-19 pneumonia with comparable disease severity. Yet, a direct or specific inhibitory effect of TSH secretion by COVID-19 could not be excluded.

Taken together, available studies suggest that patients with COVID-19 admitted to the hospital had thyroid hormone pattern that mimics that occurring in non-thyroidal illness. Preliminary data suggest that prevalence of non-thyroidal illness in hospitalized patients with COVID-19 ranges from $7 \%$ to $34 \%$, increasing in parallel to underlying severity of COVID-19.

\section{Subacute Thyroiditis in General}

Subacute thyroiditis (also called de Quervain thyroiditis) is a painful form of thyroiditis associated with low-grade fever, sore throat, and fatigue [9]. It is the most common cause of anterior neck pain, which usually refers to the jaw [9]. Women are affected more than men with 4:1 ratio. Classically, it has 3 stages: initial thyrotoxic stage of 3-6 weeks due to destructive thyroiditis, followed by mild hypothyroidism lasting up to 6 months, then most patients return to euthyroid within 12 months [9]. Approximately $5-15 \%$ develop permanent hypothyroidism. Etiology of subacute thyroiditis is likely viral [9]. This form of thyroiditis is unlikely autoimmune since only $25 \%$ of patients have antithyroid antibodies in low titers [9].

\section{Subacute Thyroiditis in COVID-19}

Only 4 well-documented cases of subacute thyroiditis were reported in relation to COVID-19 [10-13] (Table 1). All patients were successfully treated with glucocorticoids Meanwhile, in an Italian retrospective study of 287 patients hospitalized for COVID-19, Lania et al [14] reported that 31 patients (10.8\%) might have thyroiditis. This was based on the observation that it was transient and serum free T4 normalized spontaneously within 10 days in the 7 patients who were re-tested [14]. In addition, in none of 9 of the 31 patients tested for several thyroid antibodies, these antibodies were detected, a finding consistent with the nonautoimmune nature of subacute thyroiditis $[9,14]$. Nevertheless, the diagnosis of subacute thyroiditis in the series of Lania et al [14] was questionable as there was no mention of neck pain in any of their 31 patients. An alternative diagnosis could be silent (painless thyroiditis) [14].

Although the mechanism of thyroiditis associated with COVID-19 are not fully understood, it is known that subacute thyroiditis can occur in conjunction or more frequently few weeks after viral infection [15]. There are 2 potential mechanisms whereby thyroiditis occurs in COVID-19. The first mechanism may be related to the activation of immune system and inflammatory markers during COVID-19. Such activation may trigger thyroiditis by yet unknown mechanism. In support of this hypotheses, the finding of Lania et al [14] who reported that thyrotoxicosis in the subgroup of patients with possible thyroiditis was significantly 


\section{Journal of Endocrinology and Thyroid Research}

associated with higher serum levels of the cytokine interleukin-6 (IL-6) (odds ratio 3.25, 95\% CI, 1.97-5.36, P <0.001) [14]. A second possibility is that, thanks to the abundance of ACE2 receptors in thyroid gland as mentioned earlier, SARS-Cov-2 may directly invade thyroid tissue and cause destructive thyroiditis. Indeed, in severe acute respiratory syndrome (SARS) caused a related coronavirus (SARS-Cov-1), thyroid gland was affected by extensive injury of follicular and parafollicular cells [16].

Table 1: Reported cases of thyroiditis in association with COVID-19.

\begin{tabular}{|c|c|c|c|c|}
\hline Study & Ippolito et al [10] & Asfuroglu and Ates [11] & Brancatella et al [12] & Ruggeri et al [13] \\
\hline Patient's characteristics & 69-year-old woman & 41-year-old Caucasian woman & 18-year-old woman & 43-year-old woman \\
\hline Clinical presentation & $\begin{array}{c}\text { Palpitations, insomnia, agitation (no } \\
\text { neck pain) }\end{array}$ & $\begin{array}{c}\text { Neck pain and tenderness on } \\
\text { exam, normal sized-thyroid, } \\
\text { fever } 38.5 \mathrm{C}\end{array}$ & $\begin{array}{l}\text { Neck pain radiating to the jaw, } \\
\text { fever } 37.5 \mathrm{C} \text {, palpitations }\end{array}$ & $\begin{array}{c}\text { Fever } 37.5 \mathrm{C} \text {, neck pain, trem- } \\
\text { ors, palpitations }\end{array}$ \\
\hline $\begin{array}{l}\text { Timing of thyroiditis in relation } \\
\text { to COVID-19 }\end{array}$ & $\begin{array}{l}\text { Day } 5 \text { after hospitalization for } \\
\text { COVID-19 }\end{array}$ & $\begin{array}{l}\text { COVID-19 diagnosed same time } \\
\text { of thyroiditis }\end{array}$ & $\begin{array}{l}15 \text { days after diagnosis of } \\
\text { COVID-19 }\end{array}$ & $\begin{array}{l}\text { Approximately } 6 \text { weeks after } \\
\text { diagnosis of COVID-19 }\end{array}$ \\
\hline Thyroid antibodies & $\begin{array}{l}\text { Anti-TPO, anti-TSH-R, and anti-Tg } \\
\text { antibodies were undetectable }\end{array}$ & Not reported & $\begin{array}{l}\text { Anti-TPO, anti-TSH-R were unde- } \\
\text { tectable, but anti-Tg antibodies } \\
\text { were } 120.2 \mathrm{IU} / \mathrm{ml}(\mathrm{N}<30)\end{array}$ & $\begin{array}{l}\text { Anti-TPO, anti-TSH-R, and } \\
\text { anti-Tg were undetectable }\end{array}$ \\
\hline Treatment & $\begin{array}{l}\text { Methylprednisolone } 40 \mathrm{mg} \text { IV for } 3 \\
\text { days, then } 25 \mathrm{mg} \text { prednisone/d orally } \\
\text { then gradual tapering over } 4 \text { weeks }\end{array}$ & $\begin{array}{l}\text { Prednisolone } 16 \mathrm{mg} / \mathrm{d} \text { then } \\
\text { tapering over } 4 \text { weeks }\end{array}$ & $\begin{array}{l}\text { Prednisone } 25 \mathrm{mg} / \mathrm{d} \text { then taper- } \\
\text { ing. Symptoms resolved within } \\
1 \text { week. }\end{array}$ & $\begin{array}{c}\text { Prednisone } 25 \mathrm{mg} / \mathrm{d} \text { followed } \\
\text { by tapering }\end{array}$ \\
\hline Outcome & Recovery after 10 days of treatment & $\begin{array}{l}\text { Marked improvement on pred- } \\
\text { nisolone and hospital discharge }\end{array}$ & $\begin{array}{c}\text { Spontaneous recovery after } 4 \\
\text { days }\end{array}$ & Recovery after 4 weeks \\
\hline Other tests & $\begin{array}{l}\text { Increase thyroglobulin } 187 \mathrm{ug} / \mathrm{L} \\
\qquad(\mathrm{N}=3.5-77) .\end{array}$ & $\begin{array}{l}\text { Increased ESR134 mm/h, C-re- } \\
\text { active protein } 101 \mathrm{mg} / \mathrm{dl}\end{array}$ & $\begin{array}{c}\text { Tg } 5.6 \mathrm{ug} / \mathrm{L} \text { (normal range not } \\
\text { reported) }\end{array}$ & $\operatorname{Tg} 188$ pg/ml (N 0-40) \\
\hline Thyroid nuclear scan & No thyroid uptake in Tc 99-scan & Not reported & Not reported & $\begin{array}{l}\text { Markedly reduced uptake in } \\
\text { Tc 99-scan }\end{array}$ \\
\hline Thyroid ultrasound & $\begin{array}{l}\text { Enlarged hypoechoic thyroid, } \mathrm{mg} / \mathrm{L} \\
\text { ( } \mathrm{N}<1 \text { decreased vascularity and } 3 \mathrm{~cm} \\
\text { thyroid nodule (known from before) }\end{array}$ & $\begin{array}{l}\text { Decrease vascularity, heteroge- } \\
\text { neous parenchyma }\end{array}$ & Multiple hypoechoic areas & $\begin{array}{l}\text { Diffusely enlarged and hypoe- } \\
\text { chogenic thyroid }\end{array}$ \\
\hline
\end{tabular}

All cases had suppressed TSH and elevated T4 and/or T3 levels

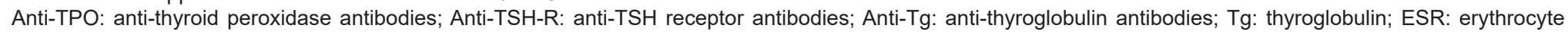
sedimentation rate

\section{Autoimmune Hypothyroidism in COVID-19}

De novo primary hypothyroidism was uncommonly reported in hospitalized patients with COVID-19. In the relatively large cohort reported by Lania et al [14], only 2 of 287 patients (0.6\%) had overt hypothyroidism, and 13 patients (4.5\%) had subclinical hypothyroidism (i.e. mildly elevated TSH, but normal T4 levels). Unfortunately, thyroid antibodies were not reported. Therefore, an autoimmune etiology could not be determined, and these cases might have non-thyroidal illness during the recovery stage as mentioned earlier [14]. To the best of the authors' knowledge, only one case of autoimmune (Hashimoto's) hypothyroidism was reported in a patient with COVID-19. Thus, Tee et al [17] described a Chinese 45-year-old Chinese man who was diagnosed with primary hypothyroidism 7 days after the onset of mild COVID-19. Thyroid peroxidase antibodies were elevated consistent with autoimmune etiology of primary hypothyroidism [17].

\section{Clinical implications of thyroid abnormalities in patients hospitalized with COVID-19}

Based on the available data, the authors recommend against routine screening of thyroid function in hospitalized patients with COVID-19 due to the following reasons. First, the common prevalence of non-thyroidal illness, a condition that does not require treatment based on current evidence in non-COVID-19 patients and frequently create confusion regarding interpretation of the thyroid hormone results. Second, a recent retrospective study found that there was low value in testing inpatients for thyroid disorders and testing caused significant expense to the health care system [18]. Third, our recommendation agrees with guidelines of American Thyroid Association and American Association of Clinical Endocrinologists that emphasize that TSH measurement should be done only if there is an index of suspicion for thyroid dysfunction [19]. In the meantime, thyroid function should be assessed in hospitalized patients with COVID-19 having any symptoms or signs of thyroid dysfunction (e.g. unexplained tachycardia or bradycardia, any kind of arrhythmia, heart failure) or clinical picture suggestive of thyroiditis (e.g. neck pain, unexplained fever).

\section{Conclusion and Current needs}

Available evidence suggests that hospitalized patients with COVID-19 have non-thyroidal illness like the pattern observed in other hospitalized patients. Small number of patients with COVID-19 develop subacute thyroiditis likely triggered by the 
causative virus of COVID-19. Evaluation of thyroid function in hospitalized patients with COVID-19 is indicated in presence of any pertinent symptoms or signs. Otherwise, routine measurements of thyroid hormones in hospitalized patients with COVID-19 may have low yield and may create confusion or lead to unnecessary investigations or treatment. Further studies are urgently needed to determine the prevalence and characteristics of thyroid abnormalities in the setting of COVID-19.

\section{References}

1. Vaduganathan M, Vardeny O, Michel T, John J V Mc Murray, Marc A Pfeffer, et al. (2020) Renin-Angiotensin-Aldosterone system inhibitors in patients with Covid-19. The New England Journal of Medicine 382(17): 1653-1659.

2. Li M, Li L, Zhang Y, Wang X (2020) Expression of the SARS-CoV-2 cell receptor gene ACE2 in a wide variety of human tissues. Inf Dis Poverty 9(1): 45.

3. Van den Berghe G (2014) Non-thyroidal illness in the ICU: a syndrome with different faces. Thyroid 24 (10): 1456-1465.

4. Fliers E, Bianco AC, Langouche L, Boelen A (2015) Thyroid function in critically ill patients. Lancet Diabetes Endocrinol 3(10): 816-825.

5. Li T, Wang L, Wang H, Gao Yufeng, Hu Xianwei, et al. (2020) Characteristics of laboratory indexes in COVID-19 patients with non-severe symptoms in Hefei City, China: diagnostic value in organ injuries. Eur J Clin Microbiol Infect Dis 1-9.

6. Sun L, Song F, Shi N, Xiong Chen, Yuxin Shi, et al. (2020) Combination of four clinical indicators predicts the severe/critical symptom of patients infected COVID-19. Journal of Clinical Virology 128: 104431

7. Chen M, Zhou W, Xu W (2020) Thyroid Function Analysis in 50 Patients with COVID-19: A Retrospective Study. Thyroid

8. Haugen BR (2009) Drugs that suppress TSH or cause central hypothyroidism. Best Pract Res Clin Endocrinol Metab 23(6): 793-800.
9. Samuels MH (2012) Subacute, silent, and postpartum thyroiditis. Med Clin North Am 96 (2): 223-233.

10. Ippolito S, Dentali F, Tanda ML (2020) SARS-CoV-2: a potential trigger for subacute thyroiditis? Insights from a case report. J Endocrinol Invest 43(8): 1171-1172.

11. Asfuroglu Kalkan E, Ates I (2020) A case of subacute thyroiditis associated with Covid-19infection. J Endocrinol Invest 43 (8): 11731174.

12. Brancatella A, Ricci D, Viola N, Sgrò D, Santini F, et al. (2020) Subacute Thyroiditis After Sars-COV-2 Infection. J Clin Endocrinol Metab 105(7): dgaa276.

13. Ruggeri RM, Campenni A, Siracusa M, Frazzetto G, Gullo D (2020) Subacute thyroiditis in a patient infected with SARS-COV-2: an endocrine complication linked to the COVID-19 pandemic. Hormones (Athens) 16:1-3.

14. Lania A, Sandri MT, Cellini M, Mirani M, Lavezzi E, et al. (2020) Thyrotoxicosis in patients with COVID-19: The THYRCOV. Eur J Endocrinol 183(4): 381-387.

15. Desailloud R, Hober D (2009) Viruses and thyroiditis: an update. Virol J 6:5.

16. Wei L, Sun S, Xu CH, He FJ, Gu J (2005) Pathology of the thyroid in severe acute respiratory syndrome. Human Pathol 38: 95-102.

17. Tee LY, Hajanto S, Rosario BH (2020) COVID-19 complicated by Hashimoto's thyroiditis. Singapore Med J

18. Dogra P, Paudel R, Panthi S, Evan Cassity, Lisa R Tannock (2020) Low yield of thyroid-function tests in adult hospitalized patients- A retrospective analysis. Int J Gen Med 13: 343-349.

19. Gharib H, Guttler RB, Tourtelot JB, Hossein Gharib, Richard B Guttler, et al. (2002) American Association of Clinical Endocrinologists medical guidelines for clinical practice for the evaluation and treatment of hyperthyroidism and hypothyroidism. Endocr Pract 8(6): 457-469.

\section{Your next submission with Juniper Publishers will reach you the below assets}

- Quality Editorial service

- Swift Peer Review

- Reprints availability

- E-prints Service

- Manuscript Podcast for convenient understanding

- Global attainment for your research

- Manuscript accessibility in different formats

( Pdf, E-pub, Full Text, Audio)

- Unceasing customer service

Track the below URL for one-step submission https://juniperpublishers.com/online-submission.php 